\title{
Coles Creek Culture and the Trans-Mississippi South
}

Frank F. Schambach

Unknown

Follow this and additional works at: https://scholarworks.sfasu.edu/ita

Part of the American Material Culture Commons, Archaeological Anthropology Commons, Environmental Studies Commons, Other American Studies Commons, Other Arts and Humanities Commons, Other History of Art, Architecture, and Archaeology Commons, and the United States History Commons

Tell us how this article helped you.

This Article is brought to you for free and open access by the Center for Regional Heritage Research at SFA ScholarWorks. It has been accepted for inclusion in Index of Texas Archaeology: Open Access Gray Literature from the Lone Star State by an authorized editor of SFA ScholarWorks. For more information, please contact cdsscholarworks@sfasu.edu. 


\section{Coles Creek Culture and the Trans-Mississippi South}

Creative Commons License

(c) $)$ (i) @

This work is licensed under a Creative Commons Attribution-NonCommercial 4.0 International License 


\section{COLES CREEK CULTURE AND THE \\ TRANS-MISSISSIPPI SOUTH}

Frank F. Schambach

Certain Lower Mississippi Valley (LMV) traits, mostly Coles Creek ceramic traits, but also traits such as temple mounds and certain mortuary patterns, appear at Late Fourche Maline and Early Caddo sites in the Trans-Mississippi South, particularly at sites in the Red River Valley in northwest Louisiana and southwest Arkansas (Schambach 1971, 1982a, b). Explaining how these traits got there and understanding their role in the development of Caddo culture is one of the basic problems in the archaeology of this area. The conventional explanation has long been that they represent a full scale intrusion of Coles Creek culture into the Trans-Mississippi South (Dickinson and Lemley 1939). Thus Michael Hoffman (1970:151-157; 1971:779-780) has created a Crenshaw phase of Coles Creek culture in the Great Bend region of the Red River Valley in southwest Arkansas, and Clarence H. Webb attributed the initial major occupation at the Mounds Plantation site in northwest Louisiana to "Coles Creek peoples" who "laid out the plaza, possibly constructed Mound 2 as a quadrilateral temple substructure, and--at the opposite end of the plaza--established a burial area where Mound 5 sits" (Webb and McKinney 1975:119-120).

James A. Ford, who knew Coles Creek culture as well as anyone ever will, objected to thus usage thirty years ago, an objection I consider perfectly valid today. Ford (in Davis 1961:113) said that "the term Coles Creek has been misused in the past. Coles Creek peoples had a distinct area, not extending very far west. It runs from the mouth of the Red River west to Alexandria, and by the Mississippi to below Vicksburg."

My position is that Coles Creek culture did not penetrate the Trans-Mississippi South and that few, if any, of the so-called Coles Creek traits we find at Fourche Maline and Caddo sites in the Red River Valley came directly out of the Coles Creek heartland. Most of them appear to be generic LMV traits that were only acepted into Late Fourche Maline and Early Caddo culture after considerable modification. To me, this indicates diffusion of selected LMV traits into this area over several hundred years (as the range of Coles Creek pottery types at sites in the Trans-Mississippi South clearly shows) probably from multiple sources within the LMV, some of which were outside the territory of Coles Creek culture as defined by Ford (1951). The main source--as I will argue below--was probably the Plum Bayou culture of the Arkansas River Lowlands (cf. Rolingson 1982).

Naturally, the major arguments in this debate involve the Coles Creek pottery of the Trans-Mississippi South. I published a study of this pottery nine years ago (Schambach 1982b:165-172), so all I need do here is review my conclusions. The basic conclusion is 
that we never find complete Coles Creek ceramic assemblages (to say nothing of complete Coles Creek cultural assemblages) at sites in the Trans-Mississippi South. The full range of Coles Creek types, including some important ones, did not diffuse to this area. Instead we invariably find a limited range of LMV decorated types (never plain wares) appearing as minority types in late Fourche Maline and Early Caddo assemblages. Pottery resembling Coles Creek Incised is the most common. Pottery now mistakenly called French Fork Incised is next in frequency. Occasionally we see some Beldeau Incised. But we never see the bread-and-butter Coles Creek types Chevalier Stamped and Mazique Incised, or the perhaps somewhat more exotic type, Ponchartrain Check-Stamped. The absence of Chevalier Stamped is particularly significant in view of Phillip's (1970:64) observation that, whenever Coles Creek Incised is found, Chevalier Stamped is "almost invariably" found with it.

The so-called Coles Creek Incised pottery of the Trans-Mississippi South is a mixed bag of pottery with Coles Creek attributes that can be divided into four groups. Group 1 is bogus Coles Creek Incised sherds that came from Caddo pots with Coles Creek-like rim designs. Since the Caddo ceramic tradition is derived in part from the Coles Creek ceramic tradition, rim sherds from at least eleven Caddo types with horizontally incised rims can be mistaken for certain varieties of Coles Creek Incised. I suspect that 30 to 50 percent of all the Coles Creek Incised identified in the literature of the Trans-Mississippi South is misclassified rim sherds from vessels of various Caddo types. Some sherds would only fool an inexperienced analyst, others would fool anyone. Take away this pottery and the apparent Coles Creek influence in the Trans-Mississippi South is considerably diminished.

Group 2 is pottery with Coles Creek designs on distinctive local pastes, particularly bone-tempered pastes, but also including grit temper and mica temper. At least 10 percent of the Coles Creek Incised pottery from southwest Arkansas sites is bone-tempered, and so is some of the French Fork Incised pottery. Bone-tempering is an old Fourche Maline trait, going back to about 500 B.C. (Schambach 1970), and a good indication that local potters were borrowing Coles Creek designs from somewhere in the LMV. We also find in the Trans-Mississippi South flat bottomed jars or beakers with Coles Creek decoration on the rims. Flat bottomed jars have a long history in the Trans-Mississippi South but they are less common in Coles Creek ceramic assemblages, where bowls predominate.

Group 3 is practically a null group. It is pottery that looks like real Coles Creek pottery made by real Coles Creek potters. Occasionally I see sherds like this and they suggest some kind of direct contact with Coles Creek culture. But for every one of these sherds there are dozens that deviate from Coles Creek norms. 
Group 4 is this deviant Coles Creek pottery, and it includes most of the Coles Creek Incised pottery of the Trans-Mississippi South. This pottery does not quite match pottery from the Coles Creek heartland in either paste or design. As has been pointed out time and again (Ford 1951:125; Wood 1963:12; Webb and McKinney 1975:77), the paste of southwest Arkansas and northwest Louisiana Coles Creek Incised is different from the Coles Creek Incised of central Louisiana. Central Louisiana Coles Creek Incised is a hard, high-fired, fine-grained, often polished, gray ware. But this Group 4 pottery is a thicker, softer, coarser, lower-fired, often unpolished, reddish-brown ware (Ford 1951:125; Newell and Krieger 1949:118; Wood 1963:12; Webb and McKinney 1975:77). Since paste is a basic criterion for types in the Phillips (1970:26) classification for the LMV, these differences must be taken seriously. Those who consider this pottery real Coles Creek pottery, as opposed to Coles Creek designs on local paste, can only do so by writing off these differences as due to properties of local clays that were beyond ther control of the potters. I contend that they reflect the superior techniques of central Louisiana potters. Had these potters or their techniques been present in the Trans-Mississippi South, we would see it in the pottery. Even if they could not duplicate Coles Creek paste exactly, I do not think they would have simply adopted the inferior Fourche Maline paste.

The designs on this pottery also tend to be slightly off-key, at best, and frequently they are at the extremes of the LMV varieties. For every sherd with a decoration that really fits a LMV variety, there are a frustrating dozen that deviate in some way. Even the best TransMississippi South Coles Creek is not really good LMV Coles Creek. Almost everyone recognizes this, which is why this pottery is often referred to as "Northwest Louisiana Coles Creek", or "Red River Coles Creek" or "Webb's Coles Creek", as opposed to the "good" Coles Creek of the LMV.

There are two ways this off-key Coles Creek pottery can be classified within the Phillips type/variety system. One is the traditional way, which is based on a normative-diffusionist model. That is, you look at the sherds and try to guess which LMV variety the local potters were trying to produce, in their own poor way. The other way is to follow Phillips's (1970:27) rule of continuity which states that "a typological unit having split distribution in space or time, even though the pottery cannot be sorted, should be automatically separated into varieties." By applying this rule to Coles Creek Incised pottery from the Toltec site in the Arkansas River Lowland region and the Crenshaw site in the Great Bend region, Martha Rolingson and I have found close ceramic ties between these regions that were not apparent before. Much of the "deviant" Coles Creek Incised of the Great Bend region fits easily into new varieties that also appear in the Arkansas River Lowland region. For example, two of our new Coles Creek Incised varieties, Keo and Lonoke (Rolingson 1982: 
Figure 31b-d), dominate certain Coles Creek period assemblages in both regions, but are rare, if not absent, at Coles Creek sites in central Louisiana.

The outstanding example of a misidentified Coles Creek type in the Trans-Mississippi South is the so-called French Fork Incised pottery found at Crenshaw and many other sites in southwest Arkansas but rarely, if ever, in northwest Louisiana (Lemley 1936: Plates 7 \& 8; Dickinson 1936: Figure 16, G1; Hoffman 1970:158; Harrington 1920: Plate LXVIIb; Webb and McKinney 1975). Because of its very complex and undeniably French Fork body designs, this type has always seemed to be compelling evidence of direct LMV influence in southwest Arkansas during Coles Creek times. But it is more likely that it was developed in southwest Arkansas, perhaps at Crenshaw itself, by Fourche Maline potters who were taking liberties with certain LMV designs.

The French Fork designs on this pottery are invariably on the vessel bodies (Weeden Island-style) rather than on the rims where they should be on French Fork Incised, while the rims almost invariably bear a Coles Creek Incised design, usually with one or two lip lines. So here we have pots that are loaded with LMV decorative attributes, which ought to make them good LMV pots, but they are actually too good to be true. They have too many LMV attributes and some of them are in the wrong places. What we are seeing here, I think, is the first expression in any southwest Arkansas pottery type of one of the basic traits of the Caddoan ceramic tradition, the use of different rim and body designs on the same vessel. It is significant that these vessels are usually flat bootomed jars out of the Fourche Maline tradition rather than bowis out of the Coles Creek tradition. This pottery, long thought to be the best example of an intrusive LMV type, is actually our best candidate for the earliest recognizable Caddoan pottery type. Phillips (1970:83; also Brain 1971:63) has obscured this point by using a pot (or its identical twin) from the Crenshaw site in southwest Arkansas as the type specimen for French Fork Incised, without giving its provenience or noticing that the French Fork design is in the wrong place for a LMV vessel. Nor does he mention that (again, foreshadowing the Caddo ceramic tradition) the original vessel is red-slipped and has white pigment in the incised lines and in the background stippling. In my forthcoming report on the Crenshaw site I am renaming this pottery Lemley Incised in hono of Judge Harry J. Lemley's pioneering work at Crenshaw.

The complex patterns of reinterpretation and recombination of diffused LMV traits that we see in these pottery types are also apparent in traits outside the ceramic complex. Although Coles Creek style flat-topped mounds were being built in the Fourche Maline 7 period (A.D. 700-900), such as Mound C at Crenshaw and perhaps Mound 2 at Mounds Plantation (Webb and McKinney 1975:119), there is no evidence that these mounds had temples, charnel houses, or dwellings on top (Schambach 1982b:156). The Fourche 
Maline people and the Early Caddo accepted the idea of flat-topped mounds from the LMV, but they used them as a new kind of burial mound, in keeping with their ancient, ultimately Hopewellian tradition.Apparently all the important Early Caddo sites such as Crenshaw and Bowman in Arkansas, Gahagan and Mounds Plantation in Louisiana, and the Davis site in east Texas have these templeless flat-topped mounds with deep grave shafts sunk through them (Hoffman 1971; Schambach 1982b; Story 1972; Webb and Dodd 1939; Webb and McKinney 1975).

There are many significant differences between the group burials in the deep pits in these mounds, with their carefully arranged skeletons and abundant grave goods, and the sanitary landfill-style mass burials without grave goods at the Greenhouse site (Ford 1951:Figure 11). These differences must reflect major differences in social organization and ceremonial orientation between Coles Creek culture in the LMV and late Fourche Maline and Early Caddo cultures in the Trans-Mississippi South. The often abundant offerings in these graves stand in strong contrast to the "unrelieved lack of grave goods" that John Belmont (1967) finds characteristic of Coles Creek culture. If Belmont is right, this adds an ironic twist to the interpretation of all the so-called Coles Creek Incisaed and French Fork Incised pots that have come from graves in the Trans-Mississippi South. Each one is proof that the grave in which it was placed was not a Coles Creek grave.

The main LMV ties of the Late Fourche Maline and Early Caddo cultures of the Red River Valley seem to be with the Toltec site and Plum Bayou culture rather than with the Coles Creek culture in central Louisiana. My working hypothesis is that the Louisiana segment of the border between the Lower Mississippi Valley and the Trans-Mississippi South was closed to massive movement. Possibly the great Red River Raft was already in place by A.D. 700, or earlier, blocking traffic up and down the Red River Valley, as it did later on in the Caddo period. Or perhaps this was a deeply hostile frontier, or simply a closed frontier, between peoples with major cultural and linguistic differences (particularly the latter). Proponents of the idea of Coles Creek culture in the Trans-Mississippi South never consider the language question, the probability that the Fourche Maline people of the Trans-Mississippi South were speaking proto-Caddo, while the Coles Creek people were speaking proto-Natchezan. Indeed, if the Coles Creek influence on the Trans-Mississippi South was as massive as they claim, and as recent (A.D. 700 to A.D. 1100), how are we to explain the major linguistic differences between these two areas at the historic date line? 
Note

This paper was originally presented in a symposium titled Coles Creek and its Neighbors at the Southeastern Archaeological Conference, New Orleans, October 20, 1988.

\section{References Cited}

Belmont, John S.

1967 The Culture Sequence at the Greenhouse Site, Louisiana. Proceedings of the 23rd Southeastern Archaeological Conference, Bulletin 6:27-35.

Brain, Jeffrey P.

1971 The Lower Mississippi Valley in North American Prehistory. Ms on file, Arkansas Archeological Survey, Fayetteville.

Davis, E. Mott (editor)

1961 Proceedings of the Fifth Conference on Caddoan Archeology. Bulletin of the Texas Archeological Society 31:77-143.

Dickinson, Samuel D.

1936 Ceramic Relationships of the Pre-Caddo Pottery from the Crenshaw Site. Bulletin of the Texas Archeological and Paleontological Society 8:56-69.

Dickinson, Samuel D. and Harry J. Lemley

1939 Evidences of the Marksville and Coles Creek Complexes at the Kirkham Place, Clark County, Arkansas. Bulletin of the Texas Archeological and Paleontological Society 11:139-189.

Ford, James A.

1951 Greenhouse: A Troyville-Coles Creek Period Site in Avoyelles Parish, Louisiana. Anthropological Papers of the American Museum of Natural History 44 (Pt. 1). New York.

Harrington, Mark R.

1920 Certain Caddo Sites in Arkansas. Museum of the American Indian, Heye Foundation, Indian Notes and Monographs, Miscellaneous Series 10. New York.

Hoffman, Michael P.

1970 Archeological and Historical Assessment of the Red River Basin in Arkansas. In Archeological and Historical Resources of the Red River Basin, edited by Hester A. Davis, pp. 137-194. Arkansas Archeological Survey, Research Series No. 1. Fayetteville.

1971 A Partial Archeological Sequence for the Little River Region, Arkansas. Ph.D. dissertation, Harvard University.

Lemley, Harry J.

1936 Discoveries indicating a Pre-Caddo Culture on the Red River in Arkansas. Bulletin of the Texas Archeological and Paleontological Society 8:25-55.

Newell, Perry H. and Alex D. Krieger

1949 The George C. Davis Site, Cherokee County, Texas. Society for American Archaeology, Memoirs No. 5. 
Phillips, Philip

1970 Archaeological Survey in the Lower Yazoo Basin, Mississippi, 1949-1955. Papers of the Peabody Museum of Archaeology and Ethnology, Volume 60. Harvard University, Cambridge.

Rolingson, Martha A. (editor)

1982 Emerging Patterns of Plum Bayou Culture. Arkansas Archeological Survey, Research Series No. 18. Fayetteville.

Schambach, Frank F.

1970 Pre-Caddoan Cultures in the Trans-Mississippi South: A Beginning Sequence. Ph.D. dissertation, Harvard University.

1971 The Trans-Mississippi South: The Case for a New Natural Area West of the Lower Mississippi Valley and East of the Plains. Paper presented at the 13th Caddo Conference, Austin.

1982a Coles Creek Culture or Coles Creek Traits in the Trans-Mississippi South. Southwest Study Unit 32 In A State Plan for the Conservation of Archeological Resources in Arkansas, edited by Hester A. Davis, pp. 92-94. Arkansas Archeological Survey, Research Series No. 21. Fayetteville.

1982b An Outline of Fourche Maline Culture in Southwest Arkansas. In Arkansas Archeology in Review, edited by Neal L. Trubowitz and Marvin D. Jeter, pp. 132197. Arkansas Archeological Survey, Research Series No. 15. Fayetteville.

Story, Dee Ann

1972 A Preliminary Report of the 1968, 1969, and 1970 Excavations at the George C. Davis Site, Cherokee County, Texas. Unpublished manuscript submitted to the National Science Foundation by the Texas Archeological Research Laboratory, Austin.

Webb, Clarence $\mathrm{H}$. and Monroe Dodd, Jr.

1939 Further Excavations at the Gahagan Mound: Connections with a Florida Culture. Bulletin of the Texas Archeological and Paleontological Society 11:92-138.

Webb, Clarence H. and Ralph R. McKinney

1975 Mounds Plantation (16CD12), Caddo Parish, Louisiana. Louisiana Archaeology 2:39-127.

Wood, W. Raymond

1963 A Preliminary Report on the 1962 Excavations at the Crenshaw Site, 3MI6. In

Arkansas Archeology, 1962, edited by Charles R. McGimsey III, pp. 1-14. Fayetteville. 